\title{
Family Dynamics in Digital Homes: The Role Played by Parental Mediation in Young Children's Digital Practices around 14 European Countries
}

Rita Brito ${ }^{1}$ (ORCID: 0000-0002-2393-2092), Rita Francisco ${ }^{2,3}$ (ORCID: 0000-0001-9101-523X), Patrícia Dias $^{2,4}$ (ORCID: 0000-0001-7948-4439), and Stephane Chaudron ${ }^{5}$

${ }^{1}$ UIDEF - Instituto de Educação, Universidade de Lisboa, Portugal

${ }^{2}$ Faculdade de Ciências Humanas, Universidade Católica Portuguesa, Portugal

${ }^{3}$ Research Center for Psychological Science (CICPSI), Faculdade de Psicologia, Universidade de Lisboa, Portugal

${ }^{4}$ Research Centre for Communication and Culture, Universidade Católica Portuguesa, Portugal ${ }^{5}$ Joint Research Center, European Commission

Running Head: PARENTAL MEDIATION IN YOUNG CHILDREN'S DIGITAL PRACTICES

Conflict of interest: The authors declare that they have no conflict of interest.

Corresponding author:

Patrícia Dias

Email: pdias@fch.lisboa.ucp.pt

Telephone number: (+351) 217214199

Address: Faculdade de Ciências Humanas, Universidade Católica Portuguesa

Palma de Cima

1649-023 Lisboa 


\begin{abstract}
In contemporary society, digital media are fully integrated in our daily lives, indispensable for our routines, always connected and at-hand. Our research thus explores the parental mediation of portable digital devices in families with young children, addressing the following questions: a) which are the most common parental mediation styles adopted towards young children; and b) which individual features of the parents or contextual factors influence the parental mediation style adopted. Our methodology is exploratory and qualitative, considering as empirical corpus 14 national reports from the European-scale study "Young Children (0-8) and Digital Technologies" for a comparative thematic analysis. The authoritative style was the most common parental mediation style related to technology use. In general, there are transversal rules to all parental mediation styles (except laissez-faire style), such as withdraw or give devices to children according to their behavior, control (inappropriate) content and control the time of use. Also, parental perceptions and attitudes about the technologies played a heavier weight on the parental mediation style adopted, and consequently influenced the relationship of the children with digital media. Some implications for future studies, preventive actions, and family therapy are discussed.
\end{abstract}

Keywords: young children; digital media; parental mediation; perceptions; practices. 


\section{Family Dynamics in Digital Homes: The Role Played by Parental Mediation in Young Children's Digital Practices around 14 European Countries}

The early 'digital natives' (Prensky 2001) are now tech-savvy parents, and children are being born in digital homes, where they are exposed to digital media since birth (Chaudron et al. 2015; Plowman and McPake 2013). This article intertwines contributes from Psychology, Media Studies and Education Sciences by arguing that, if according to Mediation Theory (Hajvard 2008), digital media are pervasive to every sphere of society and have become a meta-structure for human agency, they are also pervasive to all five systems of the ecological theory of child development (Bronfenbrenner 1979). Actually, a new dimension of the microsystem, the ecological techno-subsystem, was proposed and added to the Bronfenbrenner's model, which includes child interaction with communication, information, and recreation technologies in immediate environments, such as home or school (Johnson and Puplampu 2008).

More specifically, in the case of young children (under 8 years old), parents play an important role in their exposure and use of digital media, not only as role models, but also as gatekeepers of access to devices and content (Dias et al. 2016). The concept of parental mediation, closely related to psychological theories of parenting practices, was first suggested regarding the exposure to television, though, more recently, several theories and models concerning digital media have been developed (e.g. Valcke et al. 2010). However, family dynamics concerning young children and parents engaging with computers, consoles, tablets and smartphones are under-researched (Connell et al. 2015). The present study attempts to explore and map such complexity by comparatively describing the findings about parental mediation from a European-scale study on young children and their use of digital technologies.

\section{The Role Played by Parents in Children's Engagement with Media}


Recently, research about young children (under 8 years old) and digital media has increased, as this is the first generation of 'digitods' (Leathers et al. 2013), that is, of children born in homes filled with digital, portable and touch-screen devices (e.g. Bittman et al. 2011; Kucirnova and Sakr 2015; Livingstone 2007). One unanimous finding of these recent studies is highlighting the role played by parents in the engagement of young children with digital media, because at such an early age, they are not autonomous, and parents determine not only children's digital practices but even their access to digital devices. In addition, it is usually the parents that first introduce digital technologies to children, shaping their approach, since children look up at them as examples and role models and tend to mimic their practices and preferences (Kucirnova and Sakr 2015; Plowman et al. 2008).

Valkenburg et al. (1999) suggested that previous parental mediation styles regarding children's exposure to television could be applied to digital media and several models of parental mediation have been proposed (Valkenburg 2002; Barkin et al. 2006; Lwin et al. 2008). For example, Livingstone and Bober (2004) present an interesting perspective, distinguishing between the "material" and "symbolic" dimensions of parental mediation. The first refers to the extent to which parents use technologies and promote access to digital devices, and the latter concerns the promotion and support of digital practices and the setting and negotiation of rules.

One of the prevalent models nowadays is the matrix proposed by Valcke et al. (2010), which relates parental mediation of digital technologies to the overall parenting styles, based on Baumrind and others's work (e.g. Baumrind 1991). This model was used as theoretical grounding of the coding protocol of the European-scale study "Young Children (0-8) and Digital Technologies", whose national reports constitute the empirical corpus of this article. The authors defined two axis of parental mediation regarding internet use at home - parental control and 
parental warmth - leading to a matrix of four mediations styles: authoritative (parents set clear rules and explain them, in order to foster responsible behavior and self-regulation; the most common rule is setting a specific amount of time for using digital media), authoritarian (parents set rules without explanations and expect obedience, they are not open to dialogue and impose their own perceptions and views towards digital media), permissive (parents do not set explicit limits but monitor occasionally and negotiate with the children, rarely guiding or teaching, but rather reacting to solicitations from the children) and laissez-faire (parents do not control or engage with their children's digital practices, they do not interfere at all). More recently, Nikken and Jansz (2014) added new mediation styles specific for digital technologies: monitoring and 'helpdesk'.

\section{The Parental Mediation of Digital Media}

According to Valcke et al. (2010), the authoritative parental mediation style is the most frequent when it comes to digital media, combining high parental control and high parental warmth. Recently, Chaudron et al. (2015) found similar results in their European-scale comparative study. However, there is also a significant strand of research claiming that parents are generally permissive when it comes to using digital media in the home. One reason for that is that today's parents are 'digital natives' (Prensky 2001) themselves, and most of them are competent digital users and enjoy engaging with digital media (Plowman et al. 2008). Another important reason is that tablets are effective 'babysitters' that keep the children entertained while the parents are busy with house chores or work (Dias and Brito 2016).

At such an early age, although children are able to explore digital media independently, they frequently need guidance and help, mostly because they are not proficient in reading and writing yet. The big barrier is lack of time due to the accelerated pace of contemporary daily life, 
though some parents are concerned regarding the children's young age, which explains the fact that school is not promoting such digital practices (Dias and Brito 2016). These "paradoxes" can be explained by the parents' tendency for to report what they believe is "right", "best" or expected from them (Dias and Brito 2016). Only a small percentage of parents admits having set rules regarding internet use or screen-time (Duimel and de Haan 2007), though some rules are common in many homes, such as being allowed to play only after finishing homework and not being allowed to play for long periods of time (Dias and Brito 2016). Thus, parental control is focusing more on screen-time than on content (Wang et al. 2005). Parents claim that they prefer accompanying their children when they are online, supporting and teaching, than using filters or checking their browser historic (Beebe et al. 2004, Mitchell et al. 2005; Wang et al. 2005), though few of them report regular monitoring and supervising practices, and even filters using (Walrave et al. 2008).

\section{Variables Determining Parental Mediation Style}

Several studies attempted to identify factors that may influence the parental mediation style adopted towards the engagement of young children with digital media and understand how they work, but the findings are diverse and sometimes opposite. The earliest research on this phenomenon mostly looked at sociodemographic features, though more recent research highlighted the importance of the parents' digital practices and of their perceptions and attitudes towards digital technologies. Carvalho, Francisco and Relvas (2015) provide a systematic literature review on the adoption and use of Information and Communication Technologies (ICTs) by the families, and synthesize the factors that influence the adoption of digital media within families, their perceptions towards them and their engagement with them: socioeconomic status, geographical distance to other family members, communication strategies common in the 
family, cultural differences, satisfaction of needs, and the stage of the family life cycle. In the families with children, they found that the adoption of ICTs is more frequent, as they are regarded as a resource for school (Stevenson 2011), and it also motivates positive media consumption habits, such as choosing pedagogical content (Davies and Gentile 2012).

Concerning sociodemographic features, Aunola et al. (2000) found that mothers tend to adopt an authoritative mediation style (high control, high warmth), while fathers tend to adopt an authoritarian mediation style (high control, low warmth). Parents tend to be more permissive with boys and more restrictive with girls (Goh et al. 2015; Lwin et al. 2008; Valkenburg 2002), and older parents are more controlling, while younger parents tend to be more supporting and helpful (Wang et al. 2005). Also, the older the child is, the more restrictive parents tend to be, until that starts to be a source of conflict during adolescence, which may lead parents to become more permissive (European Commission 2008; Lwin et al. 2008; Valkenburg 2002; Wang et al. 2005). The educational background, income and profession of parents are related to varied results in research. Pauwels et al. (2008) found that parents with higher education have a more critical view of technologies and exert control over their children's practices, though in an affectionate way. They are more conscious of risks and tend to be more participative and supportive (Walrave et al. 2008; Wang et al. 2005). Duimel and de Haan (2007) reported that larger families tend to be less restrictive, as the parents are not able to supervise all the children all the time. Also, negative experiences with older siblings usually make parents more restrictive with younger siblings (Nikken and Jansz, 2014).

The literature is more unanimous on the influence of the parents' digital skills and practices. Parents with more knowledge and experience about digital media, and with more positive perceptions and attitudes towards these technologies, tend to be more controlling, as 
they are more aware of risks, but they also tend to be more participative and engaged (Barron et al. 2009; Hollingsworth et al. 2011; Nikken and Jansz 2014; Pauwels et al. 2008; Walrave et al. 2008). They also believe that supporting, guiding and teaching their children when it comes to digital media is very important (Walrave et al. 2008; Wang et al. 2005). Parents with less digital skills and experiences tend to be more permissive, but also less participative (Barron et al. 2009; Hollingsworth et al. 2011).

The present study, using as corpus of a comparative thematic analysis the 14 national reports of the "Young children (0-8) and digital technologies", conducted during 2015 under the coordination of the Joint Research Center of the European Commission, intends to answer two specific questions: a) Which are the parental mediation styles adopted towards young children around 14 European countries? and b) Which are the parents' individual features or contextual factors that influence the parental mediation style adopted?

\section{Method}

\section{Procedure}

"Young children (0-8) and digital technologies" was a qualitative exploratory project, aiming to unveil the digital practices of families with young children, based on home visits to 10 families in each country, in-depth interviews, and observation (Chaudron et al. 2015). The sample of families was purposive, and selected in each country among the personal network of contacts of the research teams, or with the help of other institutions, such as schools, associations and parishes. All the families were required to include at least one child with 6 or 7 years old with regular access to digital media, and each sample was build to showcase variety in family composition (both parents, one parent, lonely child, with older siblings, with younger siblings, etc.), education, income and geography. 
The present study focused one particular section of the reports: family narratives and indepth descriptions of each of the families and their digital practices. Data were coded according to Thematic Analysis (Boyatzis 1998) and we used QSR NVivo 11 (QSR 2015) to organize the data according to categories stemming from our research questions, the literature review, and a first reading of the narratives. Colloquial language was not corrected, so the presented transcripts are original.

\section{Participants}

The reports analysed were based on narratives from 140 families from 14 countries: Belgium (BE), Croatia (CR), Cyprus (CY), Denmark (DK), Lithuania (LV), Malta (MT), Netherlands (NL), Norway (NO), Portugal (PT), Romania (RO), Russia (RU), Slovenia (SL), Spain (ES) and Switzerland $(\mathrm{CH})$. Participant families were mostly composed of mother, father and (at least) one son/daughter under 8 years-old. Table 1 presents detailed socio-demographic information about these families, and percentages of parental mediation styles and Digital Media User's level.

\section{Results}

\section{Parental Mediation Styles Adopted Towards Young Children}

Taking into account the four styles of parental mediation related to technology use suggested by Valcke (2010), the authoritative was the most common style identified, among nine of 14 countries. Families who adopted this mediation style are concerned about controlling the apps installed by children, time of use and monitoring the visualized contents. However, the rules regarding time limits vary: there are parents who limit their children's use of digital devices on weekdays, in the morning or before bedtime, with a time limit which ranges from $15,20,30$ minutes to one or two hours a day, though during the weekend they allow more hours spent on 
these devices. Parents perceptions about technologies explain this range of limits: the better the perceptions, more time children can use technologies.

RU2 Family: Hard schedule replaces rules of Internet usage.

Most parents realize that some online content may not be appropriate for children, so they monitor content on TV and on mobile devices. If children are watching inappropriate programs on TV, parents ask them to change and see something (preferably) educational. The same happens for apps: if parents find their content to be inappropriate (usually violent), they uninstall them from the devices.

It was curious to note that some "authoritative parents" report themselves to use technologies intensively, being incoherent with the style of parental mediation they hold. Others use technology intensively outside home and control their use when they are with the family, so they can be consistent with their children's rules.

These authoritative parents have both positive and negative perceptions of technologies. Although they consider them relevant for their children's development, useful for school activities and stimulating critical thinking, they also have the opinion that it is important to encourage other kind of activities, especially the outdoors, such as being in contact with nature (i.e., going to the forest or to the beach).

Along with the authoritative style, but less represented, is the permissive style, which was mostly identified among families from Cyprus and Norway. This style is influenced by parents' positive perceptions about the use of technology by their children. Parents are active users and they consider that their children do not make excessive use of technology. Children can use the devices whenever they like, although several parents worry how much time they spend on the devices or if they access content that is not suitable for their age. 
NL3 Family: The general principle the parents described was 'freedom within boundaries'.

The less frequent parental style was the laissez-faire. The majority of the families that are driven by this parental style are of a low economic status and intense use of technologies.

Parents are not concerned about the use of devices by their children and do not supervise it. Children use them whenever they want, until the battery literally runs out. Parents are unaware of the potential of these technologies and possible risks as well as the activities that children perform on the devices.

PT8 Family: When questioned about the kind of games her son likes, the mother showed not being aware of the activities he performs with the mobile devices.

The authoritarian style was the least present. Although practiced in more countries than the laissez-faire style, its frequency was low in most of them. Nevertheless, it was the most identified in Croatia, Slovenia and Switzerland. These parents enforce rules such as time of use or restricted apps, restricting behaviour that they consider inappropriate, without negotiating them with their children. Rules are non-negotiable.

CH6 Family: I think when it comes to digital media, my rules count and I don't have to ask her about it.

Some parents are keen to accompany their children when they use the internet fearing that they have access to inappropriate content, directing them to other activities that do not involve electronics, as in going outdoors, be it playing in a garden or doing sports.

Parents' Individual Features or Contextual Factors that Influence the Parental Mediation Style Adopted

Most of the circumstances that influence parental mediation are related to children's 
excessive use of technologies, resulting in stricter rules. In most cases, when children start using technology, parents start by adopting a permissive parenting style, which may evolve into an authoritarian style, often due to a problematic situation. For example, HR1b6 used the tablet all the time, as parents did not show any concern in that. One day the child drew a man being sawed in half and covered in blood, fact which preoccupied the parents and provoked their concern. The son said he viewed this scene while watching a video and admitted that sometimes he woke up at night and play with the tablet. Other less frequent situations come from parents' personal experiences. For example, a parent, SL2f35, presented problematic use of technologies and had to seek professional help. This issue influenced her mediation behaviour towards her children, who had very strict rules of use.

Some other factors influencing the adopted parental mediation styles were identified, as presented below.

\section{Factors influencing the adoption of an authoritarian style of mediation.}

Parents who choose this style are medium and high-tech users, who describe ICTs as positive tools, especially for educational tasks such as research, improving creativity, or learning English. However, they put great emphasis on negative aspects, which prevail over positives, such as anxiety, risk of addiction, lack of socializing, promoting violence and therefore they state their use must be controlled and regulated: children must ask for permission to use such devices and cannot use them on their own, or they can only use it for a limited amount of time. If they do not respect these rules parents threaten to remove the devices by force.

In several families mother and father had different perceptions: mothers showed a restricted use and poor perceptions of technologies and more control of their child's use; fathers show good perceptions of technologies and are active users, they approve the children's use and 
play little control over them using ICTs. However, the rules imposed by the mother tend to prevail, thus opting for an authoritarian style. In these cases, fathers present a high use of technologies on a personal and professional level, use them with their children and even offer them the devices. Mothers are not as proficient as fathers when it comes to using these devices, and would prefer that fathers didn't use such technologies both for personal purpose or with their children.

NL2 Family: The parents differ considerably in their media use. Dad is a frequent smartphone user (...). Mum, on the other hand, mostly uses her phone during free time and not for work. Dad is also an enthusiastic television viewer, whereas mum hates television.

Several low income families presented negative attitudes towards technologies, with less incidence in this mediation style. For example, a mother that had difficulties in controlling her three children (one of them with Attention Deficit Hyperactivity Disorder) opted for an authoritarian mediation.

\section{Factors influencing the adoption of an authoritative style of mediation.}

Parents with this parenting style tend to be (generally) high and confident users of technologies (both personally and professionally) and have multiple digital devices at home (e.g., tablets, game consoles, smartphones). Children use these devices on a daily basis, acquiring technological skills.

Parents have usually negative perceptions of this use, fearing paedophilia, grooming and contacts with strangers through social networks, children's access to inappropriate content for their age and excessive use of technology. That is why they implement rules as time control and forbidding watching violent content. 
However, they also have positive perceptions about digital technologies that overlap the negatives, and therefore allow their daily use. Parents consider that ICTs are part of children's lives and even contribute for quality family time, such as watching a film together. Digital technologies are also useful as babysitter surrogates at restaurants and during long trips and especially for educational issues such as learning a foreign language, such as English. RU8 Family: The whole family has a positive approach to digital technologies (...), especially the father wants to introduce children to the various possibilities of use. For instance, he showed them how to make a Skype call, how to play games, how to use a programme language for children.

Parents often refer that they are high users of technology but at home they are moderate and take into account some rules established for children. Some parents who opt for this parenting style prefer to co-use and utilize active mediation strategies. They consider communication as the basis of a good relation between parents and children, behavior that they carry on to the digital use. Parents help children learn more on digital literacy, reflect on inappropriate content, contacts with strangers, pop-ups, consequences of misuse, and enhance the awareness of online photo sharing. Parents believe that in the future children will be able to use digital devices independently and correctly. Currently their role is to "teach them to protect themselves" [PT9m35]. For these parents strategies of active mediation and communication are important so children seek them whenever they have doubts or difficulties, using the internet safely. In these cases the relationship is trustworthy and the rules are not imposed, but rather discussed with children.

CY9 Family: she doesn't feel that they should have protection filters on the laptop or the computer (...) she believes that with dialogue the children can understand if they 
should do something or not.

\section{Factors influencing the adoption of a permissive mediation style.}

As with the previous parental style, parents who opt for the permissive style also have a high use of technologies and some consider themselves to be addicted. The majority are medium and high income families, using technologies professionally and at home they own several digital devices. Parents feel that their children's digital use is educational, entertaining and fun. They consider it normal for children to use technologies on a daily basis.

Children have few restrictions and parents are concerned and approach them to warn about possible online dangers. Children have some rules like not playing for too long, not accessing social networks or viewing inappropriate content. Given that they have positive perceptions, parents consider this digital exposure as very good for children.

NL4 Report: Lilou's media use is clearly a consequence of her mum's liberal stance towards digital media. Because the children (will) need to use a tablet at school, mum feels it is important they become acquainted with digital devices. She also finds them relaxing, fun and social, and enjoys playing games herself.

Even though there are few or no rules, parents are present in the children's digital lives, guiding, helping and monitoring them. They perform joint activities in the devices, stimulating educational activities such as viewing videos of animals, nature, planets, etc.

RO7 Family: the boy is clearly guided in his online adventures: when asked to show the researcher how he performs the searches, he was able to translate each step into words, much like he was probably told and explained.

Although few, there are some families in which parents make little use of technologies but have positive perceptions, as being educational, informative, challenging and necessary nowadays, hence opting for permissive mediation. 


\section{Factors influencing the adoption of a laissez-faire mediation style.}

The few parents who opt for this parenting style are mostly active users, both at home and at work, and from both high and low socioeconomic level. Low income families are not aware of positive or negative factors in ICTs use and do not bother to inquire. High income families have usually good perceptions about this use.

Among some of these families, children get up in the morning and the first thing they do is fetch a tablet, which is usually their own personal device, and use it for several hours without supervision. Some parents admit that children use technologies for too long, but are not willing to dictate rules given that they consider them as a babysitter surrogate. Thus, parents are not aware of their children's activities.

RU4 Family: Alina admits that the tablet is mostly used as a digital nanny. The father often gives it to the girl so that she is busy with something while parents solve their own issues. As a result, Camilla's access to home gadgets is unlimited. After primary school classes and at weekends she can spend up to 6-7 hours in a day with the device uninterruptedly.

\section{Discussion}

The present study intended to compare qualitative data from families from 14 European countries about the parental mediation styles adopted towards young children and the parental or contextual factors that influence them. The authoritative style was the most common parental mediation style related to technology use identified among the European families who participated to the project "Young children (0-8) and digital technologies" (Chaudron et al. 2015), finding which was in accordance with previous studies (Valcke 2010). However, in few

countries the permissive style (Norway and Cyprus) or the authoritarian style (Croatia, Slovenia 
and Switzerland) were the most common.

In general, there are transversal rules to all parental mediation styles (except laissez-faire style), such as withdraw or give devices to children according to their behavior, control (inappropriate) content and time of use (usually is allowed greater use at the weekend), in accordance with literature (Dias and Brito 2016; Wang et al. 2005). These rules stem from the importance parents give to the fact that children need to be aware of what they are doing when they use the internet. In this way they initially guide children in this use, often leaving them at ease.

The various parenting styles are associated with different perceptions that parents have about the use of technologies, their own use and the socioeconomic level. Parents who adopt an authoritative style are themselves high and confident users and have very positive perceptions (e.g. educational tasks, quality family time) related to ICTs use, but they also have some negative perceptions (e.g. addiction, exposure to violence), which balance and influence their attitudes. These parents are the ones who refer most often to co-use technologies with their children and adopt active mediation strategies, as communicate about inappropriate contents, digital literacy, consequences of misuse, etc., findings which are in accordance with literature (Pauwels et al. 2008; Walrave et al. 2008).

Parents presenting both permissive and laissez-faire Internet parenting styles are usually high technology users, and mainly identify positive perceptions, often associated with their use as babysitter surrogates (especially with regard to the laissez-faire style). In turn, parents with an authoritarian style perceptions are mostly negative, arising from the various risks associated with ICTs use, which leads them to impose strict rules that are not even discussed with their children. It was interesting to note that the opinions of mothers and fathers often differ, taking into 
account their perceptions about the technologies, which are related to their use in the day to day, both professionally and personally. Curiously, mothers seem to be more restrictive than fathers, contrary to previous studies (Aunola et al. 2000). Considering the 14 reports and the 140 families, only one mother was more permissive than the father, allowing the children to fall asleep with the television on, while their father disagreed. In the remaining families, the father was always more permissive, allowing the children to use the technologies for a longer time, in general, even motivating them in this use (e.g. to play shooting games, or to watch horror movies) or using the devices themselves fairly regularly. On the other hand, to prevent children from having access to less appropriate content, mothers prefer their children engage in nondigital activities.

Many parents point out that playing outside (and with friends) is more important than using digital technologies. Nonetheless, children often prefer spending their time playing with those technologies, which end up replacing outdoors activities and contact with other children. Because they do not want to ban technologies from their children's lives - since child interaction with communication, information, and recreation technologies at home and school are undeniable (Johnson and Puplampu 2008) -, they consider that the use of technology must be combined with other activities (e.g. cycling, play in the woods) and that it is necessary to impose rules in order to control their use.

In conclusion, we identified very diversified parental mediation styles and practices, but which consistently related to the parents' perceptions towards digital media and some sociodemographic factors. Parents who are digitally competent may reveal diversified or mixed perceptions and attitudes towards digital media, but are more participative, monitoring, scaffolding and supporting the digital practices of children. They also tend to have higher 
education and income. On the contrary, parents who are less digitally competent tend to report more negative perceptions about digital technologies, and thus to be more restrictive and less participative; however, because of their lack of information, some are very permissive.

The main limitation of the present study regards the small number of families contacted in each country. Furthermore, the identification of the Internet parental styles was based on qualitative reports, fact which might compromise the comparison with quantitative findings of previous studies (Valcke et al. 2010). Future studies focused on larger samples and using questionnaires validated in each country, could be helpful to better enlighten the Internet parenting styles adopted by most of the families and to deeper understand the interaction with other dimensions of parent-child relationship and family functioning.

\section{Implications for Practice}

Preventive actions can be drawn considering the results of the present study. For example, schools can promote educational programs on the safe use of ICTs, adapted to each age, as well as programs for parents specifically addressing internet parenting styles. On the other hand, these results also provide insight into the diversity of eventual problems related to the excessive use of digital technologies in families seeking professional help. Because parents of young children are often faced with a dilemma in the exercise of parenting without a reference model to the use of technologies (Plowman et al. 2010), it seems fundamental to help them open communicating about the risks and potentials, (re)negotiating rules about their use, and managing limits with their children (specifically the time of digital technologies use according to its purpose and context). Family therapists can specially help permissive parents thinking about specific questions (e.g., "Why do I want my child to have access to it?"; "Will this device help my child be creative and stimulate my child's imagination?"; "Will the use of this technology 
allow me to interact with my child or will it limit our interactions?"; Williams and Lee 2016).

Just as family therapists must take into account their own attitudes towards ICT, which we know can influence intervention with families on these issues (Bacigalupe, Camara and Buffardi 2014), it is fundamental that they also assess the attitudes of both parents and their relationship with sociodemographic characteristics (for example, it seems to be low-income families that present more negative attitudes towards the use of technologies). This knowledge will help therapists to discuss with families about the impact of digital technologies on family processes and to empower parents to adopt effective strategies of internet parental mediation (e.g., recommending websites, co-using) and enhance the positive influence of these technologies on families.

\section{References}

Aunola, K., Stattin, H. K., \& Nurmi, J. (2000). Parenting styles and adolescents' achievement strategies. Journal of Adolescence, doi:10.1006/jado.2000.0308

Bacigalupe, G., Camara, M., \& Buffardi, L. E. (2014). Technology in families and the clinical encounter: Results of a cross-national survey. Journal of Family Therapy, doi:10.1111/1467-6427.12042

Barkin, S., Ip, E., Richardson, I., Klinepeter, S., Finch, S., \& Krcmar, M. (2006). Parental media mediation styles for children aged 2 to 11 years. Archives of Pediatrics and Adolescent Medicine, doi:10.1001/archpedi.160.4.395

Barron, B., Martin, C. K., Takeuchi, L., \& Fithian, R. (2009). Parents as learning partners in the development of technological fluency. International Journal of Learning and Media, doi:10.1162/ijlm.2009.0021

Baumrind, D. (1991). Parenting styles and adolescent development. In J. Brooks-Gunn, R. Lerner, \& A. C. Petersen (Eds.), The encyclopedia on adolescence (pp. 746-758). New 
York: Garland.

Beebe, T., Asche, S., Harrison, P., \& Quinlan, K. (2004). Heightened vulnerability and increased risk-taking among adolescent chat room users: Results from a statewide school survey. Journal of Adolescent Health, doi:10.1016/j.jadohealth.2003.09.012

Bittman, M., Rutherford, L., Brown, J., \& Unsworth, L. (2011). Digital natives? New and old media and children's outcomes. Australian Journal of Education, doi:10.1177/000494411105500206

Boyatzis, R. E. (1998). Transforming qualitative information: Thematic analysis and code development. Thousand Oaks: Sage Publications.

Bronfenbrenner, U. (1979). The ecology of human development: Experiments by nature and design. Cambridge, MA: Harvard University Press.

Carvalho, J., Francisco, R., \& Relvas, A. P. (2015). Family functioning and information and communication technologies: How do they relate? A literature review. Computers in Human Behavior, doi:10.1016/j.chb.2014.11.037

Chaudron, S., Plowman, L., Beutel, M. E., Černikova, M., Donoso Navarette, V., Dreier, M., \& Wölfling, K. (2015). Young children (0-8) and digital technology - EU report. Luxembourg: Publications Office of the European Union.

Connell, S. L., Lauricella, A. R., \& Wartella, E. (2015). Parental co-use of media technology with their young children in the USA. Journal of Children and Media, doi:10.1080/17482798.2015.997440

Davies, J., \& Gentile, D. (2012). Responses to children's media use in families with and without siblings: A family development perspective. Family Relations, doi:10.1111/j.1741- 
3729.2012.00703.x

Dias, P., \& Brito, R. (2016). Crianças (0 a 8 anos) e tecnologias digitais [Children (0 to 8 yearsold) and digital technologies]. Lisboa: Centro de Estudos em Comunicação e Cultura, Universidade Católica Portuguesa. http://goo.gl/obFv4L. Accessed 24 March 2017.

Dias, P., Brito, R., Ribbens, W., Daniela, L., Rubene, Z., Dreier, M., Gemo, M., Di Gioia, R., \& Chaudron, S. (2016). The role of parents in the engagement of young children with digital technologies: Exploring tensions between rights of access and protection, from 'gatekeepers' to 'scaffolders'. Global Studies of Childhood, doi:10.1177/2043610616676024

Duimel, M., \& de Haan, J. (2007). Nieuwe links in het gezin [New links in the family]. http://www.scp.nl/publicaties/boeken/9789037702873/Nieuwe_links_in_het_gezin.pdf. Accessed 28 March 2017.

European Commission. (2008). Towards a safer use of the Internet for children in the EU: A parents' perspective.

http://ec.europa.eu/information_society/activities/sip/docs/eurobarometer/analyticalreport_ 2008.pdf. Accessed 24 March 2017.

Goh, W., Bay, S., \& Chen, V. (2014). Young school children’s use of digital devices and parental rules. Telematics and Informatics, doi:10.1016/j.tele.2015.04.002

Hajvard, S. (2008). The mediatization of society: A theory of the media as agents of social and cultural change. Nordicom Review, 29(2), 105-134.

Hollingsworth, S., Mansaray, A., Allen, K., \& Rose, A. (2011). Parents’ perspectives on technology and children's learning in the home: Social class and the role of the habitus. Journal of Computer Assisted Learning, doi:10.1111/j.1365-2729.2011.00431.x 
Johnson, G. M., \& Puplampu, K. P. (2008). Internet use during childhood and the ecological techno-subsystem. Canadian Journal of Learning \& Technology, 34(1), 19-28.

Kucirnova, N., \& Sakr, M. (2015). Child-father creative text-making at home with crayons, iPad collage and PC. Thinking Skills and Creativity, doi:10.1016/j.tsc.2015.05.003

Leathers, H., Summers, S., \& Desollar, A. (2013). Toddlers on technology: A parents' guide. Illinois: AuthorHouse.

Livingstone, S. (2007). Strategies of parental regulation in the media-rich home. Computers in Human Behavior, doi:10.1016/j.chb.2005.08.002

Livingstone, S., \& Bober, M. (2004). UK children go online: Surveying the experiences of young people and their parents. http://www.york.ac.uk/res/esociety/projects/1/UKCGOsurveyreport.pdf. Accessed 21 April 2017.

Lwin, M. O., Stanaland, A. J. S., \& Miyazaki, A. D. (2008). Protecting children's privacy online: How parental mediation strategies affect website safeguard effectiveness. Journal of Retailing, doi:10.1016/j.jretai.2008.04.004

Mitchell, K., Finkelhor, D., \& Wolak, J. (2005). Protecting youth online: Family use of filtering and blocking software. Child Abuse \& Neglect, doi:10.1016/j.chiabu.2004.05.008

Nikken, P., \& Jansz, J. (2014). Developing scales to measure parental mediation of young children's internet use. Learning, Media and Technology, doi:10.1080/17439884.2013.782038

Pauwels, C., Bauwens, J., \& Vleugels, C. (2008). Cyberteens: De betekenis van ICT in het dagelijkse leven van Belgische tieners. [Cyberteens: The relevance of ICT in daily life of Belgian teenagers]. http://www.eprivacy.be/SID-TIRO-PERSMAP-samenvatting-SMITVUB-120208.pdf. Accessed 24 March 2017. 
Plowman, L., \& McPake, J. (2013). Seven myths about young children and technology. Childhood Education, doi:10.1080/00094056.2013.757490

Plowman, L., McPake, J., \& Stephen, C. (2008). Just picking it up? Young children learning with technology at home. Cambridge Journal of Education, doi:10.1080/03057640802287564

Plowman, L., McPake, J., \& Stephen, C. (2010). The technologisation of childhood? Young children and technology in the home. Children \& Society, doi:10.1111/j.10990860.2008.00180.x

Prensky, M. (2001). Digital natives, digital immigrants. Part 1. On the Horizon, doi:10.1108/10748120110424816

QSR. (2015). NVivol1 Pro for Windows. QSR International Pty Ltd.

Stevenson, O. (2011). From public policy to family practices: Researching the everyday realities of families technology use at home. Journal of Computer Assisted Learning, doi:10.1111/j.1365-2729.2011.00430.x

Valcke, M., Bonte, S., Wener, B., \& Rots, I. (2010). Internet parenting styles and the impact on Internet use of primary school children. Computers \& Education, doi:10.1016/j.compedu.2010.02.009

Valkenburg, P. (2002). Beeldschermkinderen: Theorië̈n over kind en media. [Screen-kids: Theories about children and media]. Amsterdam: Boom.

Valkenburg, P., Krcmar, M., Peeters, A., \& Marseille, N. (1999). Developing a scale to assess three different styles of television mediation: "Instructive mediation", "restrictive mediation", and "social coviewing". Journal of Broadcasting \& Electronic Media, doi:10.1080/08838159909364474 
Walrave, M., Lenaerts, S., \& De Moor, S. (2008). Cyberteens @ risk: Tieners verknocht aan internet, maar ookwaakzaam voor risico's. [Cyberteens @ risk: Teenagers addicted to the internet but vigilant as to internet risks]. http://www.e-privacy.be/SID-TIRO-PERSMAPsamenvatting-survey-UA-OSC120208.pdf. Accessed 27 March 2017.

Wang, R., Bianchi, S. M., \& Raley, S. B. (2005). Teenagers' internet use and family rules: A research note. Journal of Marriage and Family, doi:10.1111/j.1741-3737.2005.00214.x

Williams, K. C., \& Lee, S. L. (2016). Focus on family: Tablets and laptops and Skype, Oh My! How do families and early childhood educators make technology decisions? Childhood Education, doi:10.1080/00094056.2016.1180934 
Table 1.

Socio demographic information about the participating countries and respective families

\begin{tabular}{|c|c|c|c|c|c|c|}
\hline $\begin{array}{l}\text { Countries } \\
\qquad(\mathrm{N}=14)\end{array}$ & $\begin{array}{c}\begin{array}{c}\text { Number } \\
\text { of }\end{array} \\
\text { Families } \\
(\mathrm{N}=140)\end{array}$ & SES (\%) & $\begin{array}{c}\text { Father: } \\
\text { Mean age and } \\
\text { DMU (\%) }\end{array}$ & $\begin{array}{c}\text { Mother: } \\
\text { Mean age and } \\
\text { DMU (\%) }\end{array}$ & $\begin{array}{l}\text { Target } \\
\text { children: } \\
\text { Mean age }\end{array}$ & $\begin{array}{c}\text { Internet Parental } \\
\text { Style (\%) }\end{array}$ \\
\hline Belgium & 10 & $\begin{array}{c}\text { 70\% High } \\
\text { 20\% Low } \\
\text { 10\% Medium }\end{array}$ & $\begin{array}{c}41.20 \text { years } \\
44 \% \text { High } \\
33 \% \text { Medium } \\
23 \% \text { Low }\end{array}$ & $\begin{array}{c}39.30 \text { years } \\
22 \% \text { High } \\
67 \% \text { Medium } \\
11 \% \text { Low }\end{array}$ & 7.1 years & $\begin{array}{l}\text { 40\% Permissive } \\
40 \% \text { Authoritative } \\
20 \% \text { Authoritarian }\end{array}$ \\
\hline Croatia & 10 & $\begin{array}{c}\text { 40\% Low } \\
\text { 30\% High } \\
30 \% \text { Medium }\end{array}$ & $\begin{array}{c}38.60 \text { years } \\
44 \% \text { High } \\
33 \% \text { Medium } \\
23 \% \text { Low }\end{array}$ & $\begin{array}{c}36.67 \text { years } \\
56 \% \text { High } \\
33 \% \text { Medium } \\
11 \% \text { Low }\end{array}$ & 6.2 years & $\begin{array}{l}50 \% \text { Authoritarian } \\
20 \% \text { Authoritative } \\
20 \% \text { Permissive } \\
10 \% \text { Laissez-faire }\end{array}$ \\
\hline Cyprus & 10 & $\begin{array}{c}\text { 40\% Medium } \\
\text { 40\% Low } \\
20 \% \text { High }\end{array}$ & $\begin{array}{c}37.10 \text { years } \\
22 \% \text { High } \\
67 \% \text { Medium } \\
11 \% \text { Low }\end{array}$ & $\begin{array}{c}38.70 \text { years } \\
30 \% \text { High } \\
60 \% \text { Medium } \\
10 \% \text { Low }\end{array}$ & 7.3 years & $\begin{array}{l}\text { 40\% Permissive } \\
\text { 30\% Laissez-faire } \\
\text { 20\% Authoritarian } \\
\text { 10\% Authoritative }\end{array}$ \\
\hline Denmark & 10 & $\begin{array}{c}80 \% \text { Medium } \\
20 \% \text { Low }\end{array}$ & $\begin{array}{c}35.22 \text { years } \\
\text { (DMU } \\
\text { Unknow) }\end{array}$ & $\begin{array}{c}33.78 \text { years } \\
\text { (DMU } \\
\text { Unknow) }\end{array}$ & 5.8 years & $\begin{array}{l}\text { 70\% Authoritative } \\
\text { 30\% Permissive }\end{array}$ \\
\hline Lithuania & 10 & $\begin{array}{l}60 \% \text { Low } \\
40 \% \text { High }\end{array}$ & $\begin{array}{c}39.33 \text { years } \\
44 \% \text { High } \\
56 \% \text { Medium }\end{array}$ & $\begin{array}{c}36.70 \text { years } \\
30 \% \text { High } \\
40 \% \text { Medium } \\
30 \% \text { Low }\end{array}$ & 6.5 years & $\begin{array}{l}90 \% \text { Authoritative } \\
10 \% \text { Laissez-faire }\end{array}$ \\
\hline Malta & 10 & $\begin{array}{c}50 \% \text { Medium } \\
\text { 30\% Low } \\
20 \% \text { High }\end{array}$ & $\begin{array}{c}40.78 \text { years } \\
78 \% \text { High } \\
22 \% \text { Medium }\end{array}$ & $\begin{array}{c}38.67 \text { years } \\
30 \% \text { High } \\
60 \% \text { Medium } \\
10 \% \text { Low }\end{array}$ & 6.5 years & $\begin{array}{l}60 \% \text { Authoritative } \\
30 \% \text { Permissive } \\
10 \% \text { Authoritarian }\end{array}$ \\
\hline
\end{tabular}




\begin{tabular}{|c|c|c|c|c|c|c|}
\hline Netherlands & 10 & (Unknown) & $\begin{array}{c}\text { 49.71 years } \\
\text { (DMU } \\
\text { Unknow) }\end{array}$ & $\begin{array}{c}38.40 \text { years } \\
\text { (DMU } \\
\text { Unknow) }\end{array}$ & 6.9 years & $\begin{array}{l}50 \% \text { Authoritative } \\
50 \% \text { Permissive }\end{array}$ \\
\hline Norway & 10 & $\begin{array}{l}50 \% \text { High } \\
\text { 40\% Medium } \\
\text { 10\% Low }\end{array}$ & $\begin{array}{c}40.78 \text { years } \\
\text { (DMU } \\
\text { Unknow) }\end{array}$ & $\begin{array}{c}39.60 \text { years } \\
\text { (DMU } \\
\text { Unknow) }\end{array}$ & 7.2 years & $\begin{array}{l}60 \% \text { Permissive } \\
40 \% \text { Authoritative }\end{array}$ \\
\hline Portugal & 10 & $\begin{array}{c}50 \% \text { Low } \\
40 \% \text { Medium } \\
\text { 10\% High }\end{array}$ & $\begin{array}{c}43.67 \text { years } \\
\text { 33\% High } \\
\text { 33\% Medium } \\
\text { 34\% Low }\end{array}$ & $\begin{array}{c}37.56 \text { years } \\
60 \% \text { High } \\
30 \% \text { Medium } \\
\text { 10\% Low }\end{array}$ & 6.6 years & $\begin{array}{l}\text { 40\% Authoritative } \\
30 \% \text { Laissez-faire } \\
20 \% \text { Authoritarian } \\
\text { 10\% Permissive }\end{array}$ \\
\hline Romania & 11 & $\begin{array}{l}50 \% \text { Low } \\
40 \% \text { Medium } \\
\text { 10\% High }\end{array}$ & $\begin{array}{c}36.67 \text { years } \\
\text { 33\% High } \\
\text { 44\% Medium } \\
\text { 23\% Low }\end{array}$ & $\begin{array}{c}34.64 \text { years } \\
\text { 18\% High } \\
\text { 45\% Medium } \\
\text { 37\% Low }\end{array}$ & 6.4 years & $\begin{array}{l}\text { 36.4\% Authoritative } \\
\text { 36.4\% Permissive } \\
\text { 27.3\% Laissez-faire }\end{array}$ \\
\hline Russia & 10 & $\begin{array}{c}80 \% \text { Medium } \\
20 \% \text { High }\end{array}$ & $\begin{array}{c}37.30 \text { years } \\
\text { (DMU } \\
\text { Unknow) }\end{array}$ & $\begin{array}{c}33.10 \text { years } \\
\text { (DMU } \\
\text { Unknow) }\end{array}$ & 5.4 years & $\begin{array}{l}50 \% \text { Authoritative } \\
20 \% \text { Permissive } \\
\text { 20\% Laissez-faire } \\
\text { 10\% Authoritarian }\end{array}$ \\
\hline Slovenia & 10 & $\begin{array}{c}\text { 60\% Medium } \\
\text { 30\% Low } \\
\text { 10\% High }\end{array}$ & $\begin{array}{c}36.3 \text { years } \\
\text { (DMU } \\
\text { Unknow) }\end{array}$ & $\begin{array}{c}34.7 \text { years } \\
\text { (DMU } \\
\text { Unknow) }\end{array}$ & 6 years & $\begin{array}{l}50 \% \text { Authoritarian } \\
40 \% \text { Authoritative } \\
\text { 10\% Permissive }\end{array}$ \\
\hline Spain & 11 & $\begin{array}{l}60 \% \text { Low } \\
40 \% \text { High }\end{array}$ & $\begin{array}{c}40.88 \text { years } \\
63 \% \text { High } \\
\text { 37\% Medium }\end{array}$ & $\begin{array}{l}41.91 \text { years } \\
30 \% \text { High } \\
70 \% \text { Medium }\end{array}$ & 6.6 years & $\begin{array}{l}81.8 \% \text { Authoritative } \\
18.2 \% \text { Authoritarian }\end{array}$ \\
\hline Switzerland & 8 & $\begin{array}{c}50 \% \text { High } \\
20 \% \text { Medium } \\
\text { 10\% Low }\end{array}$ & $\begin{array}{c}45.83 \text { years } \\
60 \% \text { High } \\
\text { 40\% Medium }\end{array}$ & $\begin{array}{c}37.13 \text { years } \\
38 \% \text { High } \\
25 \% \text { Medium } \\
\text { 37\% Low }\end{array}$ & 6.5 years & $\begin{array}{l}50 \% \text { Authoritarian } \\
\text { 25\% Permissive } \\
\text { 12.5\% Authoritative } \\
\text { 12.5\% Laissez-faire }\end{array}$ \\
\hline
\end{tabular}

Note. SES = Socio Economic Status; DMU = Digital Media User 